\title{
CONSOLDATED APPEAL
}

by the Secretary-General of the United Nations

for

\section{Emergency Humanitarian Assistance for Afghanistan \\ (June - December 1992)}

June 1992 
UN I T E D

OFFICE OF THE SECRETARY.GENERAL IN AFGHANISTAN AND PAKISTAN (OSGAP)

NA T IO N S
1. $A R E E$

2. REF

3. Retum to $\$ B$ (POL)

The Personal Representative

of the Secrelary-General

10 June 1992

Excellency,

I have the honour to transmit to you a copy of the Consolidated Appeal by the Secretary-General of the United Nations for Emergency Humanitarian Assistance for Afghanistan, launched in New York on 5 June, together with the Press Release issued at the same time.

The Appeal urgently requests the international community to make available a total of US\$ 180 million in new resources to support United Nations emergency relief and rehabilitation activities in Afghanistan over the next seven months. The amount requested includes a $\$ 76$ million shortfall for the operation Salam Programme for 1992 .

I am sure you share my view that the emergency situation is further compounded by the unprecedented number of refugees returning home. The United Nations High Commissioner for Refugees estimates that, in the last week alone, some 7,900 people returned to Afghanistan from Iran and Pakistan every day. It is therefore of utmost importance that the international community contributes generously towards the rehabilitation of this devastated country.

I do hope that your Government will be able to respond positively to the Appeal.

Please accept, Excellency, the assurances of my highest consideration.

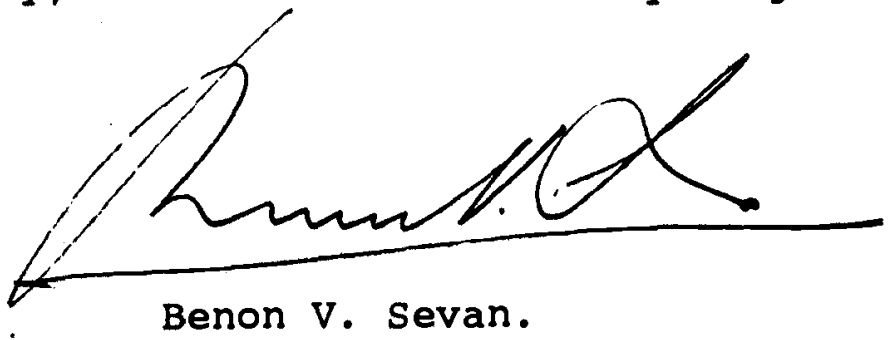

His Excellency

Mr. Nicholas Platt

Ambassador Extraordinary and Plenipotentiary

Embassy of the United States of America

Islamabad 


\section{FOREMORD}

Few countries in history have suffered to the extent Afghanistan has over the past fourteen years. Aside from the physical destruction, which was often nothing short of cataclysmic, the results of the war include well over a million people killed, over two million disabled, nearly six million refugees in neighbouring countries, and two miliion internally displaced persons.

Even before the war, Afghanistan was one of the poorest countries in the world. Today, it has the highest infant mortality rate and the lowest literacy rate in the world.

For over a decade now, millions of Afghan refugees in exile in Iran and Pakistan have endured appalling conditions eking out a meagre existence. The plight of those who stayed behind was no better. They have been obliged to seek shelter in the remains of their bombed-out villages, never knowing when they or their families will lose their limbs or their lives because of the millions of mines that litter large tracts of the country.

The tasks of emergency relief, rehabilitation and reconstruction are immense. Most of the country's infrastructure lies in ruins, and almost an entire generation has lost out on even a basic education. One of the most serious tasks facing Afghanistan will be to reintegrate into civilian life the hundreds of thousands of men who know no other life except war.

The international community has an obligation to see that the people of this desperate land-locked country have a chance to better the miserable circumstances in which they live. They must be provided an opportunity to live in conditions of relative dignity and security.

Many governments have contributed toward the humanitarian needs of the Afghan people since 1988. I now appeal to all donors to contribute as generously as possible to a country whose people have borne such indescribable suffering with so much fortitude.

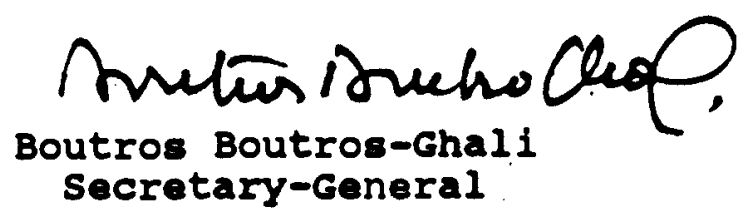




\section{MAP OF AFGHANISTAN}

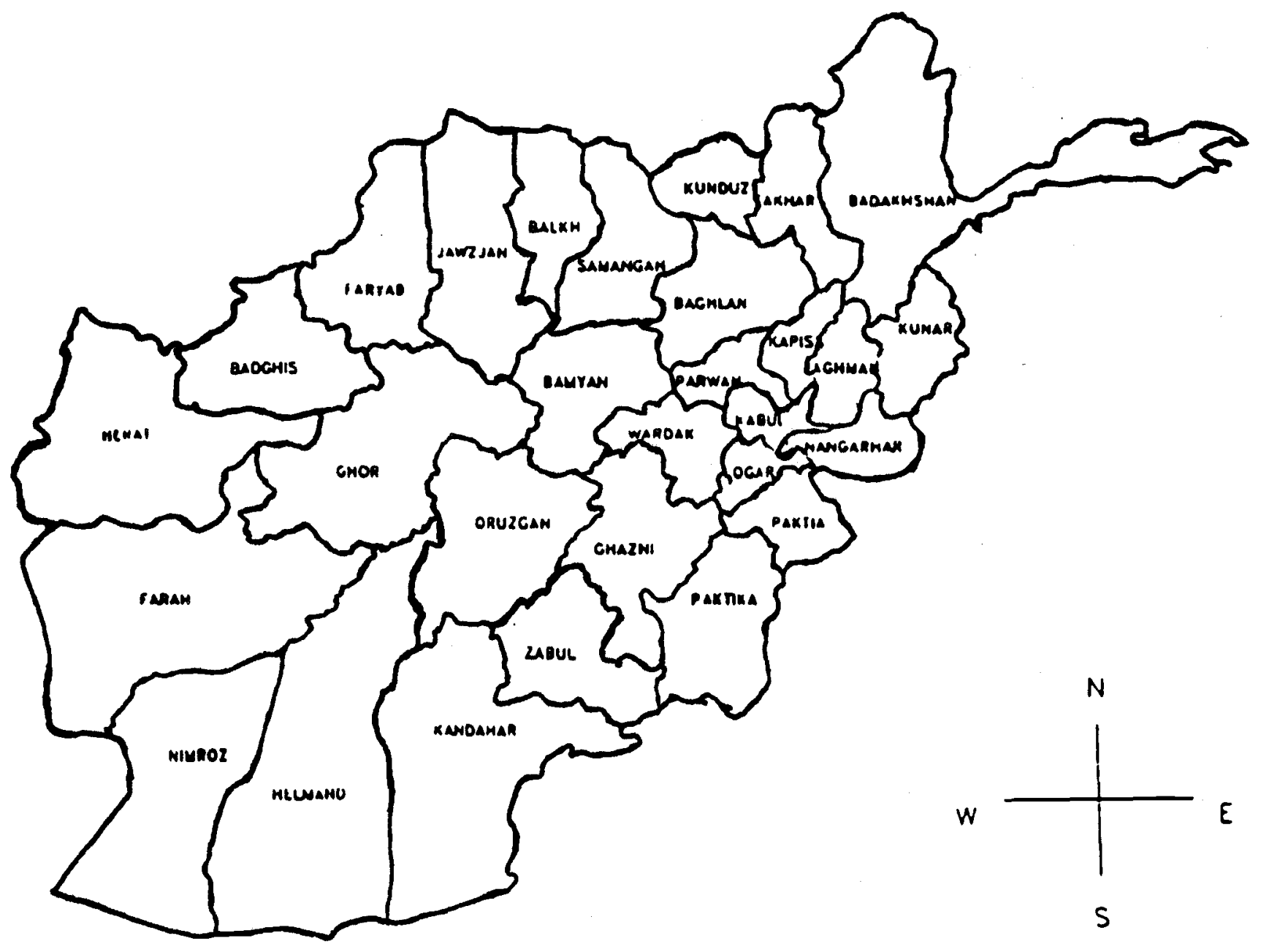


TABLE OF CONTENTS

Paragraphs Paes

Executive summary.............................

I. INTRODUCTION....................1-11

II. FOOD AID.........................12-30

III. HEALTH, WATER SUPPLY AND ENVIRONRENTAL

SANITATION........................... 31-43

IV. MINE CLEARANCE..................44-52

v. VOLUNTARY REPATRIATION..............53-73

vI. AGRICULTURE..................... 74-77

vII. EDUCATION........................78-81

VIII. REHABILITATION OF INFRASTRUCTURE........82-85

IX. DRUG ABUSE CONTROL.................86-88

X. WOMEN IN DEVELOPMENT....................

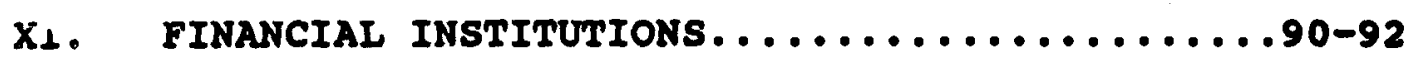

XII. COORDINATION SERVICES...............93-95

\section{ANNEX}

I. Total Funding Requirements..................... 33

II. Food Ald Requirements: Initial Repatriation Phase.......34 (June-December 1992) 


\section{Executive summary}

This Appeal requests the international community to provide new resources totalling US\$ 180 million to United Nations agencies for emergency humanitarian assistance for Afghanistan until the end of the current year. The resources requested include a shortfall of over US\$ 76 million in the ongoing Operation Salam Programe for 1992 .

The main sectors of the Appeal are Food Aid (US\$45.1 million), Health, including Water Supply and Sanitation (US\$30.6 million), Mine Clearance (US\$15 million) and voluntary Repatriation (US\$52.8 million). Support is also urgently required for existing programmes of the United Nations agencies in the fields of Agriculture, Education, Rehabilitation of Infrastructure and Drug Abuse Control.

The level of destruction in Afghanistan is hard to imagine unless witnessed at first hand. Whole villages have been razed to the ground, main roads and irrigation systems have disintegrated, many school buildings have been totally destroyed, and health services in urban areas have collapsed. In addition millions of mines are scattered in many parts of the country. It is in these conditions of deprivation that the country awaits the return of 6 million refugees.

The newly-established Government of the Islamic State of Afghanistan, and the new provincial councils based in the main cities, are trying to grapple with these basic issues. Few donor countries, and none of the international financial institutions, have yet reestablished their presence in the country. In these circumstances the humanitarian activity of the United Nations system, already well established in Kabul, and in the main cities of the neighbouring countries, assumes a critical importance. It is a matter of the greatest urgency that the United Nations agencies receive the resources necessary to meet the emergency needs of the Afghan people. 


\section{INTRODUCTION}

1. In the months preceding the recent developments in Afghanistan, basic services in the fields of health, water supply, education, electricity and communications deteriorated as the authorities lost control in the main cities and instability in many regions disrupted what remained of normal activities. supplies of essential food and other basic commodities were interrupted, as the Government faced serious logistical and financial difficulties. This situation led to appalling conditions in the hospitals in Kabul during the recent fighting, as casualties were brought in to find no water, electricity or basic medical supplies. stability and security have gradually begun to return to kabul and the main provincial cities since the Government of the Islamic state of Afghanistan took power a month ago on 28 April. Nevertheless the country is still faced with an emergency of dramatic proportions, in which almost everything is needed and almost nothing is readily available. The Government has been confronted immediately with a vast range of problems, economic and humanitarian, as well as political.

2. From 11 to 15 May 1992 a United Nations inter-agency team, led by the Personal Representative of the secretary-General in Afghanistan and Pakistan, Mr. Benon Sevan, visited Kabul and held consultations with the new authorities. The team also held consultations with the authorities in the Islamic Republic of Iran and the Islamic Republic of Pakistan. The inter-agency team comprised officials from the United Nations Development Programme (UNDP), Office of the United Nations High Commissioner for Refugees (UNHCR), the United Nations Children's Fund (UNICEF), the United Nations office for the Coordination of Humanitarian and Economic Assistance Programmes relating to Afghanistan (UNOCA), the World Food Programme (WFP) and the World Health Organization (WHO). 
3. After the events of the past months the country requires emergency assistance if the Government is to provide food for the population and reestablish the most basic services. The High Commissioner for Refugees reports that over 4,000 persons per day have been crossing back to Afghanistan from the Islamic Republic of Iran and Pakistan during April and May.

4. This Appeal identifies and addresses the most urgent needs in the fields of food aid, health, including water and sanitation, mine clearance, voluntary repatriation, agriculture, education, rehabilitation of infrastructure and drug abuse control. Total funding requirements are shown in Annex $I$. The Appeal also identifies certain basic economic problems facing the Government, which the humanitarian agencies of the United Nations systen are not in a position to address, but which must be brought to the attention of the international community for urgent consideration by bilateral donors and the international financial institutions. Foremost among these problems are the acute budget deficit and the shortage of fuel.

\section{A. Principles of the emergency operation}

5. The emergency operation will be closely coordinated with the Government. The United Nations agencies will reinforce their existing offices in several key cities in the country to act as operational bases and open additional ones in areas where the level of activity may justify it.

6. The United Nations agencies participating in the humanitarian and economic assistance programmes relating to Afghanistan, known as operation Salam, have been working over the past three years in close cooperation with non-governmental organizations (NGOs). Many of these NGOs have also brought their own funding and resources to 
the assistance programme. The United Nations agencies believe that NGOS will continue to have much to contribute to the Afghan people, and would encourage them to present their programmes to the Government.

7. A basic premise of the emergency operation is that assistance will be provided to communities on the basis of needs, with no distinction made between the returning refugees, the internally displaced and those who remained behind.

8. The Operation Salam Programme for 1992 (referred to as the Programme) described a wide-ranging programme of humanitarian assistance and initial rehabilitation work for Afghanistan to be executed by the 14 United Nations agencies participating in the Programme at a total cost of US\$ 133.7 million. Many of the activities described in this programme are already under way, although most face serious shortfalls in funding. As at 20 May 1992, US\$ 57.3 million had been made available leaving a shortfall of US\$ 76.4 million. That Programme foresaw the return of some 300,000 refugees, well under half the numbers now foreseen.

9. The present Appeal identifies emergency requirements which the United Nations agencies can meet during the coming 7 months (JuneDecember 1992), subject to availability of resources. No funds are at present available to meet the costs identified in this Appeal.

10. This Appeal addresses the most immediate needs. At this time, the United Nations system is also drawing up a medium-term Rehabilitation Strategy for Afghanistan, which is expected to be finalized by September 1992 . 


\section{B. Coordination mechanism}

11. The current Programme is coordinated by UNOCA, headed by the Personal Representative of the Secretary-General in Afghanistan and Pakistan. The Secretary-General has asked his Personal Representative to coordinate the emergency operation under the overall direction of the Under-Secretary-General for Humanitarian Affairs, Mr. Jan Eliasson. 
12. Throughout the 14-year war, food shortages and in particular shortages of the basic cereal - wheat - have existed in various parts of the country. The withdrawal of programme wheat assistance from the former Union of Soviet Socialist Republics (USSR) since 1991 has increased the chronic deficit by 250,000 tons per annum. There are at present numerous localized food emergencies, both in the rural areas and in the cities especially Kabul. The imminent return of large numbers of refugees will add to the need for cereal imports in direct proportion to the numbers returning.

13. On 6 April 1992 the Secretary-General appealed to the international community for 30,000 MT of food aid for the city of Kabul. The response has been quick and generous although access to Kabul by road has limited deliveries so far. WFP has steadily increased deliveries from Pakistan, using a variety of routes, and has successfully delivered over $1,600 \mathrm{MT}$, with a further $500 \mathrm{MT}$ en route and preparations are under way for 5,000 MT to be transported on WFP's own trucks.

14. The annual average wheat deficit in Afghanistan is considered to be about 600,000 tons, which has been met in the past by a combination of programme food aid, project food aid and commercial imports. It is this deficit, together with sufficient wheat to feed the increased population as a result of repatriation, plus special requirements for vulnerable group feeding and ration card encashment, which are reflected in this Appeal.

15. The calculation of food needs is given in Annex II. Donors are reminded that all food aid must be accompanied by sufficient cash grants to finance moving the food into Afghanistan (i.e. internal transport, storage and handling (ITSH) from the port of discharge). 
16. In order to meet a requirement for direct distribution by WFP of 198,500 MT of wheat from June to December 1992, pledges of a further 100,500 NT are required. Some 46,000 MT of this should be delivered via the Islamic Republic of Iran, 23,000 WT via Termez in Uzbekistan and 31,500 MT via Karachi in Pakistan. The value of the additional food requested for direct distribution, including international freight, is estimated at us\$ 24 million.

17. In addition to ITSH funds already available with WFP, a further US\$ 16.6 million will be required in 1992 to complete the direct distribution deliveries in this plan.

18. WFP will need an additional US $\$ 900,000$ for monitoring and staffing costs, US\$ 1.6 million for an expanding logistics infrastructure inside Afghanistan and US\$ 2 million for non-food support to community assistance projects.

19. Donors are also requested to supply 208,500 MT of programme food aid, for which transport costs have not been included in this Appeal.

20. The components of the food aid programme are described below. It is recommended that all food aid is routed through WFP either as a multilateral contribution or as a bilateral contribution for which WFP services are provided. This will enable WFP to properly coordinate the arrival, storage, monitoring and reporting of the contributions made.

\section{A. Emergency assistance through free distribution}

21. Free distribution may be the only response to critical situations, particularly in the cities, with distribution being made through whatever is judged to be the most effective channel. For example, WFP has been assisting with the supply of wheat to the Kabul bakeries in order to supply bread to the capital. In 
undertaking free distribution, WFP will rely on common assessments made in different regions of Afghanistan by United Nations staff under a local coordinator, and by voluntary agencies. In many cases it is considered that a ration of wheat and vegetable oil will be sufficient to address the situation; however, a component for feeding the most vulnerable groups has also been included. Free distribution will continue for as short a time as possible. Whenever possible, WFP would prefer to replace it with food-forwork activities aimed at community support.

\section{B. Food-for-work activities}

22. It is WFP's objective to meet the basic cereal needs and provide employment in Afghanistan to the greatest possible numbers of the most needy during this emergency and initial repatriation phase. In doing so, basic rehabilitation activities will be supported. WFP will provide wheat assistance to communities on the basis of payment of a basic wheat ration for the completion of jointly identified community works such as the repair of feeder roads, schools, community buildings, bridges, clearance and repair of irrigation networks etc. The wages for non-skilled labour will be set at $7 \mathrm{~kg}$ of wheat per workday which, although more than the normal cereal requirement of a family, does not represent a wage that will attract labourers away from working on agricultural activities or from any cash-based employment that may be available.

23. As a large number of projects will have to be implemented rapidly over a wide area, a system of piece-work payments will be utilized which ensure completion of agreed targets that can be managed and monitored with limited staffing. Assistance will be paid in instalments and will be terminated if targets are not met in a reasonable time. For the most part, projects requiring a simple design will be attempted. More complex projects, provided that they are supported by non-food inputs from government, or other United Nations or NGO resources, will also be considered. 
In addition to the provision of food and transport, WFP will provide community assistance projects with tools, cement and other materials that are essential. The payment of cash wages to skilled workers will be the responsibility of the implementing partner.

24. From what will be a broad range of large and small comnunity works, a number of projects may emerge which would in the medium term attract additional funding and become the framework for longer-term rehabilitation and reconstruction development projects.

\section{c. Repatriation grant}

25. There is an ongoing UNHCR/WFP operation in Pakistan to provide $300 \mathrm{~kg}$ of wheat and 3,300 Pakistani rupees (currently valued at US\$ 130) as a repatriation grant in exchange for each ration card. Details of this operation are described in paragraph 62 below. This has proved to be a viable method of assisting individual families to return. The inclusion of wheat in the repatriation grant has become all the more important in Pakistan with the Government's readiness to allow returning families to take household supplies including wheat but limiting other food exports not covered under this plan. The $300 \mathrm{~kg}$ of wheat given is a sufficient wheat ration for an average family for three to four months.

26. WFP will make a similar repatriation grant arrangement in the Islamic Republic of Iran to provide wheat to returning refugees. As there are a large number of refugees without families in the Islamic Republic of Iran, $50 \mathrm{kgs}$ of wheat will be provided to each refugee returning. The distribution of wheat will be made before departure from Iran.

\section{Programme food aid for sale/budgetary support}

27. It is recommended that the difference between the overall food aid needs and the quantities to be used for direct distribution be 
supplied by donors in the form of programme aid for budgetary support either through WFP or directly to the Government of Afghanistan. Afghanistan has in recent years received large quantities of such aid, particularly from the former USSR. It has been used to supply government bakeries in the major cities and for food payments to civil servants and others as part of an institutionalized coupon system. At the present time, the Government is buying limited amounts of wheat from the Kabul bazaar in order to keep the system in partial operation. Only 10,000 tons of wheat are available in the Kabul silo, enough to supply bakeries, coupon holders and others at a limited rate for only 20 days. Government silos in other major cities are equally or worse off and a serious shortage of wheat is being faced throughout the country. As has been noted in other sections of the present document, the Government has inherited a very precarious financial situation and all means of budgetary support are welcome. Food aid in particular would be suitable for the foreseeable future.

28. In addition to wheat it is clear that there are also serious shortages of other basic food commodities, although not on the same scale. Estimates have been made of minimum amounts of vegetable oil and sugar that could be provided for market sales to relieve acute shortages and to provide funds for budgetary support either bilaterally or through WFP. The Government of Pakistan has agreed that an equivalent volume of any commodities monetized in Pakistan, should that be required as a part of this operation, will be allowed to be exported into Afghanistan through private sector export permits.

\section{E. Transfer to Afahanistan of food assistance currently provided to refugees in the Islamic Republic of Iran and Pakistan}

29. An essential part of successful refugee repatriation will be that the international community maintains assistance levels to 
refugees in the Islamic Republic of Iran and Pakistan at the current level of over 430,000 MT a year at least through 1993. The refugees will either be in camps or will have returned and, in either case, will need assistance. Ensuring successful repatriation will of course reduce the long-term demands on donors of refugee assistance. Individual and family assistance in the Islamic Republic of Iran and Pakistan will end at the point of the payment of the repatriation grant, thus eventually releasing supplies from camp feeding for the food aid programme inside afghanistan.

\section{F. Logistics and personnel}

30. WFP will continue, in principle, to provide logistics support to the United Nations system in Afghanistan and Pakistan. Logistics management operations will be transferred to Kabul as it becomes feasible to do so. WFP is establishing logistics bases at the main provincial headquarters from where it will provide transport, storage and handling support. WFP will also maintain a fuel reserve at these locations for United Nations operations. WFP will strengthen its personnel at the provincial level to ensure appropriate project design and monitoring. 
III. HEALTH, WATER SUPPIY AND MNVIRONIFNTAC SANTTATION

31. Even before the war, the health indicators and facilities for Afghanistan ranked among the worst in the world. But in the months preceding the recent transfer of power in Kabul, what little infrastructure there was in the areas of health, nutrition, water supply and sanitation almost completely collapsed owing to the severe fighting.

32. Medicines and basic health supplies were severely depleted and access to food supplies, particularly for vulnerable groups, became difficult in the urban areas. Inadequacies in the water supply were exacerbated by the lack of electricity, leading to a further deterioration in sanitation and the supply of potable water.

33. As a result, the Government is faced with immediate emergency requirements if it is to deliver vital social services for the general public, including a large influx of returnees.

\section{A. Strategy}

34. The Operation salam approach has been to empower communities themselves to address emerging local problems. This communitybased approach will continue to serve as the basis on which to deliver health, water supply and environmental sanitation services.

35. Research indicates that many of the Afghan refugees in the Islamic Republic of Iran and Pakistan have grown accustomed to the facilities available in urban centres, even if they originate from rural areas. If they decide to return to urban settlements, where the quality of social services is already inadequate, the resulting sudden increase in population will put enormous pressure on such services. There is therefore a particular need to strengthen existing facilities within the next few months. 
36. Improvements in health, water supply and sanitation will focus both on areas indicated by UNHCR as likely places for settlement by returnees and on provincial capitals, as a starting-point for later rehabilitation activities. The capitals of the following provinces will be treated as flrst priority: Balkh, Bamyan, Ghazni, Helmand, Herat, Kabul, Kandahar, Kunduz, Nangahar, Nimruz, Paktia. In addition, assistance with health, nutrition and drinking water for travelling returnees, especially mothers and children, will be coordinated by UNHCR.

37. To improve services quickly, there will be close collaboration between United Nations agencies, NGOs and the national and local authorities. Several important wCOs are already working in these fields.

\section{B. Procaramme components}

38. Assistance to communities to cope with the current emergency situation described above w11l include action to bolster health services, the supply of potable water, sanitation and supplenents of essential food and micronutrients. Both preventive and curative health activities will be supported by UNICEF and wHO and will include the following components:

(a) Uporading hospitals and provision of medical supplies

39. Assistance will be given to increase the capacity of hospitals in the towns and health centres in rural areas through supply of essential drugs, vaccines and cold chain, surgical equipment and other medical supplies and materials. These will be important for providing general curative, referral and public health services and for war and mine-related injuries. 
40. Supplementary food, oral rehydration solution (ORs) and micronutrients will be distributed to vulnerable young children and pregnant women.

\section{Disease and epidemic control}

41. There is an urgent need to control the possible outbreak of epidemics which could occur with the influx of refugees into Afghanistan. Particular attention will be paid to the control of tuberculosis, meningitis and malaria. For the latter the introduction of second line anti-malarial drugs is needed to address the problems of chloroquine-resistant malaria.

\section{operational costs}

42. Because of the lack of infrastructure, additional funds are needed for operational costs which will include transport and logistics, fuel, back-up generators, temporary staff, volunteers and other personnel.

\section{Water supply and environmental sanitation}

43. Rapid repairs of current non-functioning water supply and sanitation facilities, extension of existing installations and the establishment of new ones will be carried out with the support of UNDP and UNICEF. This will entail the provision of supplies and equipment to communities which will implement these projects through food and cash for work. 


\section{c. Funding requirements}

\section{BUDGET \\ (in millions of US\$)}

\section{A. Health}

1. Upgrading of hospitals and provision 6.8 of medical supplies

2. ORs, high protein foods and micronutrients

3. Disease and epidemic control

4. Operational costs

5. Emergency training of health workers

6. Procurement of raw materlal for local essential drug production

B. Water supoly and sanitation

1. Water supply and environmental

13.2

sanitation 


\section{YINE CLEARANCE}

\section{A. Present situation}

44. Mines and unexploded ordnance represent the nost cruel and indiscriminate obstacle to a return to normal life in Afghanietan. since conflict was often most intense in areas from which refugees and displaced persons have fled, mines and unexploded ordnance are inevitably present in many of the areas to which they are now planning to return. Thus many refugees will feel unable to return until mines have been cleared, and those who do not wait will face great danger as they try to reestablish themselves. Mines which were laid in villages, roads, agricultural land and irrigation systems will remain a hazard in many parts of the country for years to come.

45. Surveys of mined areas totalling $66 \mathrm{sq} \mathrm{km}$ in 14 provinces have already been carried out, and UNOCA now employs 41 trained surveyors on this task. However, owing to security reasons it has so far been impossible to begin survey work in some of the key areas around major cities, and in rural areas to which many refugees now wish to return.

46. Over 1,200 Afghans are currently employed full-time on mine clearance work. A small mechanical mine clearance unit, with two "flail" machines, has worked in paktia and Paktika provinces. Fifty mine detection dogs have recently been incorporated into the UNOCA programme, in support of the mine clearance teams. Until now, it has not been possible to begin mine clearance in some of the most heavily mined areas, owing to security reasons.

47. As a result of recent events in Afghanistan, the possibility now exists to expand the programme substantially. It is essential that this is done quickly in order to respond to the huge demand already being experienced following the start of large-scale 
voluntary repatriation, and before the ground hardens in winter.

\section{B. Immediate reoulrements}

48. The immediate need is for:

(a) The deployment of mine awareness teams in the areas to which refugees are returning;

(b) A comprehensive survey and marking programme throughout Afghanistan;

(c) A rapid increase in the number of mine clearance teans, to respond to increased demand;

(d) The redeployment of existing mine clearance teams to new areas of priority concern;

(e) The acquisition of appropriate mechanical mine clearance vehicles.

\section{Programme components}

49. Mine awareness training teams will focus on the major border crossing points and transit areas, as well as towns and villages to whlch refugees are returning. Awareness messages will also be broadcast on local radio and television.

50. A detailed plan has been prepared for a comprehensive survey of all mined areas in Afghanistan. Urgent funding is required to enable the work to start.

51. Discussions are under way with the Government to initiate training courses in mine clearance techniques for over 500 men. These courses will take place at a number of training camps in 
Afghanistan during the second half of 1992. After training, the men will be equipped and incorporated into the existing programme. They will be deployed in areas of high priority, in consultation with the Government. Funds are also required to obtain and operate four additional fully equipped mechanical mine clearance vehicles.

52. A total of US\$ 25 million is required immediately to fund this programe for the period until the end of 1992 . 


\section{v. VOLUNTARY REPATRIATION}

53. Recent developments in Afghanistan have led to a significant increase in the number of refugees wishing to return home during 1992. While many refugees are still waiting to be sure that there has been a definitive cessation of hostilities and an end to insecurity in their home areas, it is clear that large-scale repatriation to Afghanistan has already begun. Its pace is likely to accelerate with the restoration and consolidation of peace. The number who return in 1992 will depend on security within Afghanistan, and the success of the efforts of the international community to help meet Afghanistan's emergency and immediate rehabilitation needs.

54. The Government of the Islamic Republic of Iran reported that 1,000-1,400 Afghans were repatriating daily in mid-May. As arrangements for organized assistance are put in place, the Government expects the rate of return to increase to 2,500 per day, and that a total of 525,000 will repatriate during the remainder of 1992.

55. In Pakistan, 2,500-3,000 families (15,000 individuals) were presenting themselves each week in April-May to exchange their ration cards for a repatriation grant. At the same time, UNHCR monitoring staff have observed some 3,000 refugees per day repatriating to Afghanistan through the main border crossings. If this rate were maintained, 100,000 families $(600,000$ individuals) would repatriate during the remainder of 1992.

56. Taking account of the many uncertainties, resources are now requested to support the voluntary repatriation from the Islamic Republic of Iran and Pakistan of the next one million returnees. There are reported to be almost 3 million Afghans in Iran, of whom 2.25 million are registered, and some 3.2 million in Pakistan, of whom 2.7 million are registered. If developments in Afghanistan 
lead to a higher number of Afghans wighing to return before the end of 1992, requirements will be adjusted accordingly.

57. The budget takes account of contingency stocks and available resources, and thus reflects additional needs. Many details of the operation within Afghanistan and from the Islamic Republic of Iran remain to be worked out. The budget will be adjusted as required should different priorities or needs become apparent.

58. As in any voluntary repatriation, the fundamental principle of free choice must be respected. The refugees themselves will decide when to return. UNHCR will seek to ensure that this is an informed decision. Most humanitarian assistance provided in Afghanistan will be to communities rather than individuals. In meeting needs, no distinction will be made on the basis of status between the internally displaced, returning refugees, and those who remained behind. As far as possible, assistance will be provided in a way that promotes early self-sufficiency and stimulates the recovery of the local economy.

59. The Governments of the Islamic State of Afghanistan, the Islamic Republic of Iran and the Islamic Republic of Pakistan have agreed to the establishment, with UNHCR, of two tripartite commissions on voluntary repatriation in order to facilitate arrangements for return.

\section{A. Protection}

60. The Tripartite Repatriation Commissions will provide a framework within which the basic protection issues can be addressed. All the Governments concerned are committed to the principle of voluntary repatriation. The Government of the Islamic State of Afghanistan has expressed its determination to ensure the safety of returning refugees. UNHCR will monitor repatriation to confirm its voluntary character and the safety and security of

$$
-20-
$$


returnees. UNHCR presence along major routes of return and at the principal border crossings will be maintained and expanded to cover the returnees' home areas.

\section{B. Direct assistance to returning refugess}

\section{Repatriation from the Islamic Republic of Iran}

61. Refugees requesting voluntary repatriation will be assisted by the Government's Bureau for Aliens and Immigrant Affairs (BAFIA), with transport to assembly points near the border on the main exit routes. From these points, transport will be arranged either direct to the refugees' home districts, or to transit centres in Afghanistan from which further transport assistance will be arranged for those with far to go. Provision is made for ONHCR support for transport to homes, where these are near the border, or to the transit centres. It is intended that each returning refugee will receive $50 \mathrm{~kg}$ of wheat and each family will receive a tarpaulin for temporary shelter until families can reconstruct their houses. New transit facilities may be required at the assembly and border crossing points where existing facilities are insufficient, and provision is made for assistance for the establishment/expansion of these.

\section{Repatriation from Pakiatan}

62. Registered refugees are assisted with the cost of return and initial reintegration through the repatriation grant. Begun in 1990 by UNHCR and WFP in cooperation with the Government of Pakistan, the grant is a cash/wheat package given to returning families in exchange for ration cards, and is currently valued at some US\$ 130 plus $300 \mathrm{~kg}$ of wheat per family.

63. Three quarters of the registered refugees in pakistan are within one day's travel time of their places of origin, and are 
expected to make their own transportation arrangements, utilizing funds provided under repatriation grant. Those who have longer distances to travel would make their way to the reception/transit points within Afghanistan from which arrangements would be made for further transport assistance. It is recognized that for many of the unregistered and for vulnerable refugees, organized transport will be required. However, it is expected that the great majority of returns in 1992 will be made with the assistance of the repatriation grant. The Government of Pakistan is also providing limited organized transport as a complement to the repatriation grant.

\section{Transportation assistance within Afghanistan}

64. Returnees travelling long distances will be provided with assistance with transport from established reception/transit points to their home districts. It would appear that herat, Kandahar and Kabul may be priority locations for the establishment of such points. At least a quarter of the refugees in the Islamic Republic of Iran and Pakistan might need onward transport. However, it is difficult at this stage to predict the demand for transportation requirement and its costs. Transportation to home areas will also be required by the internally displaced within Afghanistan. Following the policy that assistance within Afghanistan should be provided on the basis of need, not prior status as refugees, internally displaced families will benefit from the programme.

65. The Afghan authorities have agreed in principle that the International organization for Migration (IOM) would take responsibility for this sector on behalf of UNHCR.

\section{c. Assistance to returnee communities}

66. Once they are home, returning refugees will be included along 
with the other members of their communities in the programes of the United Nations and other agencies for emergency assistance and initial rehabilitation.

67. Different local conditions and needs, as well as varying levels of destruction and depopulation, preclude the distribution of a uniform relief package for each returning family or the prescription of a single programme of assistance for each community. United Nations staff for each area will work with local authorities, community representatives and non-governmental organizations to identify and prioritize needs and to develop the programmes required to meet immediate needs and to facilitate the process of reintegration.

68. While it is clear that shelter will be a major need, it is not yet possible to quantify the immediate requirements. Limited stocks of shelter and relief materials will be maintained in locations to be determined. Provision is also made for additional funds to support community-based reconstruction of homes. Implementing arrangements will be agreed with the Government and the United Nations Centre for Human Settlements (Habitat).

69. UNHCR staff in the field will alert other agencies to new or unmet emergency or rehabilitation needs in places to which refugees are returning. Provision is made for UNHCR to assist other agencies when they are unable to meet the full cost of necessary activities. Projects to assist vulnerable groups will be given priority. The likely scale of needs and the many unknowns calls for UNHCR to have a significant financial and operational capacity to intervene directly in areas of refugee return when immediate needs cannot otherwise be met.

\section{Field presence and programme support}

70. UNHCR will expand its field presence in Afghanistan in order 
to cover the main expected areas of return and transit points. A presence is currently foreseen in Herat, Lashkargah, Randahar, Gardez, Jalalabad, Bamyan, Pol-e-Khomri and Mazar-i-Sharif. The fleld presence will be adjusted as required in light of the actual pattern of return.

71. In the Islamic Republic of Iran, UNHCR has opened an office in Mashhad and will open offices in Birjand and zahedan, and establish a presence at the border crossing points. The main provinces from which the longer journeys to the assembly points are expected to be organized are Ahvaz, Isfahan, Kerman, Khoramabad and zanjan. UNKCR has an office in Ahvaz and will establish a presence in the others, and elsewhere as needed, in order to monitor the arrangements and start the process of coordinating planned returns to Afghanistan.

72. In Pakistan, the UNHCR field house network will be maintained, as will a presence at the principal border crossing and transit points. Additional encashment and distribution points for the repatriation grant programme will be opened as required.

73. Provision is made for the purchase of vehicles and communications equipment where needs cannot be met by redeployment or from reserves, and for essential programe support at UNHCR headquarters. 
E. Funding requirements

\author{
BUDGET \\ (in millions of US\$)
}

1. Protection

2.2

2. Direct assistance for 1 million returnees

25.0 (transit facilities, food, repatriation grant, tarpaulins, transport)

50,000 WT of wheat is provided by WFP

(see Food Aid)

3. Transportation within Afghanistan

5.0

4. Assistance to returnee communities

12.0

5. Programme support

8.6

Total

52.8 


\section{AGRICUTIURE}

74. Agricultural production in 1991 was only 60 per cent of what it was before the war. Distribution of improved seeds and fertilizer, together with the rehabilitation of irrigation systems, is essential to revitalize the rural economy. This has becone an immediate priority with the anticipated return of large numbers of refugees to the rural areas.

75. The Programme for 1992 gave particular emphasis to the distribution of inputs for food crop production by the Food and Agriculture Organization of the United Nations (FAO), and for livestock health and the repair of irrigation systems by UNDP. The likelihood of accelerated repatriation has increased the need for these inputs beyond what was foreseen in November 1991. In addition, the acute budget deficit facing the Government in Afghanistan means that normal import programmes may not be implemented.

76. The most immediate requirement is for at least $10,000 \mathrm{MT}$ of fertilizer and 2,000 MT of improved seed for the autumn planting of the staple wheat crop. This is now a matter of great urgency. Additional packages of improved seed and fertilizer will be provided to communities in areas to which refugees and displaced persons are returning, to the extent that funds and supplies become available. The rehabilitation of irrigation systems will also be supported under the community assistance projects executed by WFP under its food-for-work programme. Technical support and complementary funding for these projects will continue to be provided by UNDP. Other priority activities in the agriculture sector include crop protection, the procurement of tractors and veterinary services.

77. The funding requirement for agriculture programmes is US\$ $\mathbf{2 1 . 6}$ million. 


\section{EDUCATION}

78. As soon as the Government took power, it decreed that the schools in Kabul should be reopened and the teachers report to work. This was followed in almost all provincial capitals. During the war more than 2,000 teachers were killed, 2,000 schools were destroyed and 15,000 teachers left the profession. Afghanistan thereby lost generations who received no schooling, and the literacy rate is the lowest in the world.

79. One of the fears confronting refugees considering return to Afghanistan is that there will be no schooling for their children, many of whom have attended school in the Islamic Republic of Iran and Pakistan. Support for the education sector will therefore be a priority for United Nations efforts in Afghanistan in the coming years.

80. During the emergency phase UNICEF and the United Nations Educational, Scientific and Cultural organization (UNESCO) will concentrate on providing school supplies and equipment in both urban and rural areas, as well as training. These activities were foreseen within the Programme for 1992, mainly in the context of a Basic Education Programme. Support for the repair of school buildings will be made available under the Rehabilitation of Infrastructure Programme.

81. Some US\$ 3.6 million is needed immediately to fund these projects. 


\section{REHABILITATION OF INFRASTRUCTURE}

82. Substantial investment will be sought from the international community to repair the extensive damage and neglect to the entire infrastructure of the country. Detailed assessments of the requirements will be undertaken during the summer of 1992 by the United Nations system as part of a medium-term Rehabilitation strategy for Afghanistan coordinated by UNDP.

83. While it is not possible at this stage to define these immediate needs, nor to begin work on major projects, since the Government needs to reestablish its relationship with the major bilateral donors and the international lending institutions, immediate assistance is required to carry out emergency repairs to the electricity supply network, urban water supply systems and key national highways. Although of great urgency, this work falls outside the scope of the present Appeal for emergency humanitarian assistance.

84. Within the scope of this operation, however, small-scale projects for immediate repair of rural roads and community buildings such as schools and health centres will be supported.

85. Some US\$ 9.4 million is required to carry out projects already planned within the Programme for 1992. 


\section{DRUG ABUSE CONTROL}

86. There is a danger that, without adequate international assistance, the return of refugees to their homes may lead to an increase in production of illicit drugs. While repairing their homes and putting their land back into cultivation, returning refugees, particularly in those provinces where production is already widespread, may be tempted to guarantee some immediate cash income by planting opium poppy.

87. In the circumstances prevailing in the country, United Nations agencies foresee three methods of tackling this problem:

(a) The Government will be encouraged to introduce strict regulations outlawing the production and sale of lilicit drugs. Senior members of the new administration have already denounced the production of illicit drugs;

(b) Existing programmes supported by the United Nations International Drug Control Programme (UNDCP) to make the population aware of the dangers surrounding the abuse of illicit drugs will be stepped up, and included in all United Nations education programmes;

(c) The support which this emergency operation can provide for the repair of irrigation systems and wage payments for community work will encourage existing and potential oplum growers to engage in alternative subsistence activities.

88. Some US $\$ 800,000$ is required urgently for the establishment of Drug Information Centres, supported by UNDCP, in Kabul and other major cities. 


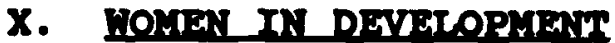

89. Uxoch has just established a fund to assist with the integration of women into programmes of assistance organized by the United Nations agencies and the first contribution has been received. UNDP has just appointed a full-time professional adviser in Kabul in the field of women in development. UNICEF is continuing the implementation of its projects for Women with special Needs. These activities in the context of the ongoing Programme will help to ensure that the emergency operation, for which funding is requested in this Appeal, also takes into full account the needs of women. 


\section{EINANCIAI INSTITUTIONS}

90. The Goverment of the Islamic State of Afghanistan faces unprecedented tasks in rehabilitation and reconstruction, and has almost no resources immediately available with which to meet the costs. The Acting Minister of Finance informed the United Nations team which visited Kabul from 11 to 15 May that his Ministry faced budget demands for routine expenditure of 666 billion Afghanis in 1992, with income of only 89 billion, a deficit of Us\$ 1.5 billion at the rate of exchange prevailing on 15 May. These figures relate only to the requirements of the parts of Afghanistan under the control of the previous government, and not to other areas. The present Government is obliged to feed and support thousands of civil servants of the former government, and of the former Afghan Interim Government as well as thousands of military men on both sides of the conflict, until other productive employment can be found for them, without the financial support previously provided to both sides by bilateral donors.

91. As a consequence of this acute budget deficit, the Government is not in a position to fund the import of several essential commodities, which requires the outlay of foreign exchange. Most noticeable at present is the severe shortage of fuel of all kinds, while shortages of fertilizer on the local markets will also be a major problem during the coming growing season, if help is not provided to import large quantities. The import of essential food items not available locally, such as vegetable oil, sugar, tea, rice and milk powder will also be affected.

92. While these budget problems fall outside the scope of the present Appeal, it is of the utmost importance that international financial institutions, as well as major bilateral donors, provide urgent and generous support to minimize the impact of the present emergency. 


\section{COORDINATION SERVICES}

93. A complex programe of emergency assistance to a country whose infrastructure is shattered, and which is chronically short of qualified administrators, requires close and effective coordination within the United Nations system and between the United Nations agencles and the Government, the non-governmental organizations and the donor Governments.

94. As noted above, the Secretary-General has asked his Personal Representative in Afghanistan and Pakistan, in his capacity as Head of UNOCA, to continue to coordinate the humanitarian activities of the United Nations agencies. During the coming months UNOCA will strengthen its presence in Kabul and the main provincial centres of Afghanistan. UNOCA's presence in the neighbouring countries will be correspondingly reduced.

95. In addition to the small aircraft currently managed by UNOCA, contribution in kind for a small cargo aircraft is requested. In order to support increased demand on UNOCA'S services the radio network will need to be expanded. For these activities as well as for the deployment of personnel in new areas, an additional us\$ 800,000 will be required in 1992 . 
at:

\section{ANNEX I}

\section{Total Funding Reouirements}

\section{BUDGET \\ (in millions of US\$)}

1. Food aid

2. Health, water supply and environmental sanitation

3. Mine clearance

4. Voluntary repatriation

5. Agriculture

6. Education

7. Rehabilitation of infrastructure

8. Drug abuse control

9. Coordination services
45.1

30.6

15.0

52.8

21.6

3.6

9.4

0.8

0.8

Total

179.7 


\begin{abstract}
ANNEX II
Food Aid Requirements: Initial Repatriation Phase

(June-December 1992)

FOOD REOUIR PAIFNTS MIN

WHEAT VEGOII DSY SUGAB
\end{abstract}

A. WHEAT DEFICIT

Overall wheat deficit, calculated

at 50000 mtn p.m.

Additional deficit, caused by

refugee return from Pakistan and

Iran

Total wheat deficit June-Dec 1992

350000

30000

380000

B. FOOD AID BREAKDOWN

1. Emergency feeding

(a) Wheat

(b) Vegoil

42000

2520

2. Vulnerable group feeding
(a) Wheat
(b) Vegoil
12000
(c) DSM
(d) Sugar
480
480
360

3. Food-for-work activities

(a) $7.5 \mathrm{~m}$ workdays at $7 \mathrm{~kg} \quad 52000$ per day supplied via Pakistan

(b) $\quad 3.0 \mathrm{~m}$ workdays at $7 \mathrm{~kg}$ per 21000

(c) $3.0 \mathrm{~m}$ workdays at $7 \mathrm{~kg}$ per 21000 day supplied via Iran

4. Repatriation grant to 1 million

returning refugees at $50 \mathrm{~kg} \mathrm{p} \cdot \mathrm{p} / 300$

kg per family

50000

5. Programme food aid for sale/ budgetary support 